\title{
Evaluation of Child Sexual Abuse Cases
}

\author{
Çocuğun Cinsel Istismarı Olgularının Değerlendirilmesi
}

\section{(1) Güven Seçkin Kırcı, MD.1, (1) Erdal Özer, Assoc. Prof. MD.1, @ İsmail Birincioğlu, Prof. MD.2, @ ( Halil ilhan Aydoğdu, MD.3, (1) Mehmet Askay, MD.4, (1) Mustafa İmamoğlu, Prof. MD. 5}

\author{
${ }^{1}$ Karadeniz Technical University Faculty of Medicine, Department of Forensic Medicine, Trabzon, Turkey \\ ${ }^{2}$ Balıkesir University Faculty of Medicine, Department of Forensic Medicine, Balıkesir, Turkey \\ ${ }^{3}$ The Ministry of Justice Council of Forensic Medicine, İstanbul, Turkey \\ ${ }^{4}$ The Ministry of Council of Forensic Medicine Trabzon Group Chairmanship, Trabzon, Turkey \\ ${ }^{5}$ Karadeniz Technical University Faculty of Medicine, Department of Pediatric Surgery, Trabzon, Turkey
}

\section{ABSTRACT}

Objective: Sexual abuse means the sexual exploitation of an individual, who is described as a child in the international treaties and national legal texts, by adults. The present study aims to reach the profile of our region, Turkey, concerning child abuse through the features of the victims applying to the center to reveal the possible differences by comparing the studies in the literature, and to define the additional risk factors to the ones known.

Methods: Our study was conducted in Trabzon Child Protection and Advocacy Center. The children who applied during a period of one and a half year, between January 2015 and June 2016, were included in this study. This study involved the retrospective evaluation of the records kept by the center.

Results: In this study, 86 (83.5\%) of children were girl, 17 (16.5\%) of them were boy, and the girl/boy ratio was 0.19 . Regarding the age groups, $19(18.4 \%)$ of them were nine years old or younger; 37 (35.9\%) of them were between 10 and 14 years old; 47 (45.6\%) of them were 15 years old and older. While the youngest age identified in our study was four, the oldest child age was 18. The average age was $13.11 \pm 3.817$ years.

Conclusion: The findings obtained in this study suggest that in child abuse, the victim hides the abuse for years due to fear, threat or believing not to be relied on and to be humiliated. Thus, victims who suffer from recurrent abuses for long years come out.

Keywords: Child abuse, sexual abuse, child protection centre 


\section{Öz}

Amaç: Çocuk istismarı, kaza dıșı ve önlenebilir bir sebeple çocuğun yetișkin bir kimse tarafından fiziki, ruhsal ya da her iki açıdan birden zarar görmesi olarak tanımlanmaktadır. Çalışmamızın amacı; merkeze başvuran mağdur çocukların özellikleri üzerinden çocuk istismarının bölgemiz profiline ulaşmak, bölgemiz özelliklerini literatür ile karşılaştırarak mevcut olabilecek farklılıkları ortaya koyabilmek, literatürce bilinen risk faktörlerine ilave risk faktörlerini belirlemek olarak sıralanabilmektedir.

Yöntem: Çalıșmamız Karadeniz Teknik Üniversitesi Tıp Fakültesi bünyesinde kurulan Trabzon Çocuk Koruma ve İzlem Merkezinde yapılmıştır. Ocak 2015 ile Haziran 2016 arasında bir buçuk yıl süreyle başvuran çocuklar bu çalışmaya dahil edildi. Bu çalışma, merkez tarafından tutulan kayıtların geriye dönük bir değerlendirmesini içermektedir.

Bulgular: Değerlendirdiğimiz 103 çocuğun cinsiyetine bakıldığında 86’sının (\%83,5) kız, 17’sinin (\%16,5) erkek olduğu, erkek/kız oranının 0,19 olduğu görülmüştür. Olguların yaş gruplarına bakıldığında 19'unun (\%18,4) 9 yaş ve daha küçük, 37'sinin (\%35,9) 10 ve 14 yaşları arasında, 47 $(\% 45,6)$ çocuğun ise 15 yaş ve daha büyük olduğu görülmektedir. Çalışmamızda tespit edilen en küçük çocuk yaşı 4 iken, en büyük çocuk yaşı

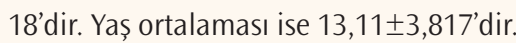

Sonuç: Çocuğun cinsel istismarında istismar mağduru çocuk, korku, tehdit, söylediklerine inanılmayacağı ve utanç verici duruma düşeceği inancıyla, maruz kaldığı istismarı yıllarca saklamakta, bu nedenle çok uzun yıllar boyunca yineleyen istismarlara maruz kalan mağdurlar ortaya çıkmaktadır.

Anahtar Kelimeler: Çocuk istismarı, cinsel istismar, çocuk koruma merkezi

\section{INTRODUCTION}

Child abuse is defined as deliberate and preventable physical or mental harm, or both together, inflicted on a child by an adult (1). Traces of child abuse can be seen throughout human history in every geographical region and every culture. In 1962, Kempe first used the term "battered child", then, this term was replaced by the term "child abuse," and with the current increasing number of specialists involved in this subject and the increasing establishment of special centers, and it has become a critical public health problem (2).

Child abuse is examined under four main headings of physical abuse, sexual abuse, emotional abuse and neglect. Within these types of abuse, sexual abuse is differentiated from the others as it is both the most difficult to be identified by physicians and is the type that has the greatest societal effects (3). Although there are several definitions in the literature, sexual abuse can be summarized as the use of a child by an adult in any way for sexual stimulation (4). Although sexual abuse is seen in not inconsiderable numbers in society, because of cases that cannot be determined, numbers are thought to be much greater, and this presents a threat of severe dimensions to public health and societal comfort. In studies that have been published concerning the sexual abuse of children, considerable differences are seen in the reported rates. The frequency of exposure to sexual abuse in childhood has been reported as 10\%-40\% $(3,5)$.

This subject, which encompasses a broad spectrum from sexual harassment to assault with the intention of penetration and child pornography to child prostitution, requires the collaborative work of several medical specialist fields, such as a forensic medicine specialist, a child psychiatrist, a pediatric surgeon and a gynecologist. In addition, when it is considered that in the judicial process of a child sexual abuse victim, it is necessary to have contact with many different disciplines, including a judge, a prosecutor, a lawyer, a psychologist and social workers, it can be clearly understood that there is a need for a comprehensive and multi-disciplinary working group at all the stages of reporting, diagnosis, judicial process and rehabilitation/treatment of child abuse.

When routine applications on this subject in Turkey are examined, it is shown that the most frequently encountered first behaviour tendency after the abuse is that $56.87 \%$ of the children hide the abuse, $20.52 \%$ of them ask their family for help and $78 \%$ of the families try to look for legal help (6). There are also cases where sexual abuse has been suspected as a result of a preliminary evaluation by a physician or incidentally when the child has presented at a healthcare institution for another health problem. In such cases, the physician is obliged to report the case to the judicial authorities. Both the process that starts with reporting the case and the process of evaluation of the case, for which the court demands an expert assessment, require medical, legal and social service personnel to work together in compatibility, collaboration and co-ordination. For justified or unjustified reasons, objections to the judicial report prepared about the case are one of the most important factors prolonging the judicial process. Extending the evaluation process with repeated questioning of the child, repeated examinations and recall of the incident may cause more traumas for the child.

It is noticeable that in recent years, there has been the establishment of centres with a multi-disciplinary approach to reduce to a minimum the iatrogenic traumatisation of the child in the medical and judicial processes, with many experts in the medical and legal field working on this subject. As a result of these efforts, child protection and advocacy centres have been 
established in Turkey to provide a service for child victims of sexual abuse (7). When a child victim of abuse is taken to these centres either by the police or healthcare authorities or by their own family, they are met by specialists on this subject and all the medical and judicial processes can be applied at once within the centre. Thus, the child is affected by the process at the minimum level. In addition to the application of the diagnostic examination and statements related to the legal process in these centres, medical and social support is provided for the child, who can then start a rehabilitation process in the shortest possible time.

The present study aims to investigate the profile of child abuse in our region through an examination of the characteristics of child victims presenting at a single centre, and by comparison with the literature to reveal any differences in the regional characteristics and determine risk factors additional to those known in the literature.

A secondary aim in this study is to investigate whether there are ways to prevent abuse by identifying the characteristics of the background of the incident and the time, place and perpetrator of the child abuse in the light of the community.

\section{MATERIALS and METHODS}

The present study was derived from the thesis entitled "Evaluation of Child Sexual Abuse Cases Aplıed to Trabzon Child Protection and Monitoring Center Between January-2015 to June 2016".

This study included children who were referred to Trabzon Child Protection and advocacy centre with a claim of child sexual abuse, which is a unit of the Karadeniz Technical University Medical Faculty, in the 18-month of January 2015June 2016. A retrospective evaluation was performed using the records kept at the Centre. Permission was granted from the ethics committee for this study. The documents of the family interview form, forensic interview form, family identification form, the victim, witness and perpetrator statements and the forensic examination reports were examined from the archives of the centre, where they were kept separately and confidentially for each child.

The data related to the victim's age, gender, medical history, education level, comorbid illnesses, the type and number of abuse and examination findings were collected from the files.

\section{Statistical Analysis}

The data obtained were input to SPSS (Statistical Package for the Social Sciences) in 23 software program.

In the comparison of categorical data of the cases, the chisquare test was used. In all analyses, a value of $p<0.05$ was accepted as statistically significant. In some cases evaluated in this study, there were no data about the parents or abuser and this resulted in a lack of information in these cases, which was one of the limitations in this study. A further limitation was that following the evaluation, the judicial processes could not be followed up and as healthcare services for the victim were provided by different units, an evaluation could not be made after the reports.

\section{RESULTS}

This study included 103 children who presented with a claim of child sexual abuse at the Trabzon Child Protection and Advocacy Centre or to the judicial authorities in the 18-month period of January 2015-June 2016.

The 103 children evaluated comprised 86 (83.5\%) girls and 17 (16.5\%) boys with a female/male ratio of 5.05 .

When the age groups of the cases were examined, 19 (18.4\%) were $\leq 9$ years, 37 (35.9\%) were 10-14 years and 47 (45.6\%) were $\geq 15$ years old. The youngest child was four years old and the oldest was 18 years old; the mean age of the study group was $13.11 \pm 3.817$ years.

When the educational status of the children was examined, most cases were primary school students $(n=32,31.1 \%)$, followed by high school students $(n=23,22.3 \%)$ and in two (1.9\%) cases. There was no information in the files about their education (Table 1).

At the time of the forensic and medical evaluations, 76 (75.2\%) children were in formal education and 25 (24.8\%) children discontinued formal education.

The medical histories of the children were examined, and it was observed that $80(77.7 \%)$ of the child victims had no physical or mental illness. Of the diseases and conditions determined, the most frequent was mental retardation in eight (7.8\%) cases (Table 2).

When the abuse was examined in respect of occurring with or without penetration of the body with an organ or another object, there was penetration in 64 (62.1\%) cases, comprising 57 (55.3\%) female children and seven (6.8\%) male children and there was no penetration in 39 (37.9\%) cases, comprising 30 (29.1\%) female children and nine (8.7\%) male children.

\begin{tabular}{|l|l|l|}
\hline Table 1. Educational status of the children \\
\hline Level of education & $\begin{array}{l}\text { Number of } \\
\text { children (n) }\end{array}$ & $\begin{array}{l}\text { Percentage } \\
\text { (\%) }\end{array}$ \\
\hline Unknown & 2 & 1.9 \\
\hline No education & 3 & 2.9 \\
\hline Pre-school & 5 & 4.9 \\
\hline Primary school & 16 & 15.5 \\
\hline Finished primary school only & 2 & 1.9 \\
\hline Middle school & 32 & 31.1 \\
\hline Finished middle school only & 9 & 8.7 \\
\hline High school & 23 & 22.3 \\
\hline Finished high school & 11 & 10.7 \\
\hline
\end{tabular}


According to the information obtained from the interviews with the child victims, there was touching of the child in 60 (58.3\%) cases, kissing in 16 (15.5\%) cases, indecent exposure in three (2.9\%) cases and verbal sexual abuse in 10 (9.7\%) cases, which were legally accepted as types of abuse, not in the nature of penetration. In 32 (31.1\%) cases, vaginal penetration was recorded, in 21 (20.4\%) cases, anal penetration, and in six (5.8\%) cases, oral contact (mouth-penis).

When the number of incidents suffered by the children was examined, a single incident was determined in 50 (48.5\%) cases (42 female, 8 male) and at least two or more incidents in 53 (51.5\%) cases (44 female, 9 male) (Table 3).

In the examinations of the children, ical findings included hymenal laceration in $20(19.4 \%)$ cases, of which 18 were old, and two were new, extragenital ecchymosis in six (5.8\%) cases, genital ecchymosis in two (1.9\%) cases, fissure in the anal region in two (1.9\%) cases, both of which were male, hymenal petechiae in two (1.9\%) cases and genital bleeding in two (1.9\%) cases.

When the examination was made of the time from the incident of abuse to examination at the centre, more than one week was seen to have passed in 66 (64.1\%) cases, between one and seven days in 28 (28.2\%) cases, and only eight (7.8\%) cases presented within 24 hours of the incident (Table 4).

When the relationship between the child and the alleged

\begin{tabular}{|l|l|l|}
\hline Table 2. Medical histories of the children \\
\hline Disease & $\begin{array}{l}\text { Number of } \\
\text { children (n) }\end{array}$ & $\begin{array}{l}\text { Percentage } \\
\text { (\%) }\end{array}$ \\
\hline No disease & 80 & 77.7 \\
\hline $\begin{array}{l}\text { Attention deficit and hyperactivity } \\
\text { disorder }\end{array}$ & 4 & 3.9 \\
\hline Down's syndrome & 2 & 1.9 \\
\hline Coeliac disease & 1 & 1 \\
\hline Asthma bronchialis & 1 & 1 \\
\hline Mental retardation & 8 & 7.8 \\
\hline Alopecia areata & 1 & 1 \\
\hline Major depression & 2 & 1.9 \\
\hline Anaemia & 1 & 1 \\
\hline Enuresis nocturna & 2 & 1.9 \\
\hline Epilepsy & 1 & 1 \\
\hline
\end{tabular}

Table 3. The number of incidents of abuse

\begin{tabular}{|l|l|l|}
\hline $\begin{array}{l}\text { Number of incidents of } \\
\text { abuse }\end{array}$ & $\begin{array}{l}\text { Number of } \\
\text { children }(\mathbf{n})\end{array}$ & Percentage (\%) \\
\hline $\mathbf{1}$ & 50 & 48.5 \\
\hline $\mathbf{2}$ & 15 & 14.6 \\
\hline $\mathbf{3}$ & 4 & 3.9 \\
\hline $\mathbf{4}$ & 4 & 3.9 \\
\hline $\mathbf{> 4}$ & 30 & 29.1 \\
\hline
\end{tabular}

perpetrator of the abuse was examined, the findings showed that the perpetrator was known to the child in some way in 94 $(91.3 \%)$ of the cases and was a stranger in only nine (8.7\%) of the cases.

The perpetrator of the abuse was a family member in 21 (20.4\%) cases, the boyfriend of the child in 19 (18.4\%) of the cases and the husband from a religious marriage ceremony in three (2.9\%) cases (Table 5).

\section{DISCUSSION}

It has been reported by the World Health Organization (WHO) that approximately $20 \%$ of females and $5 \%$ of males who participated in a study had been exposed to sexual abuse in childhood and 25\%-50\% had experienced physical violence. Poor treatment in childhood leaves lifelong negative effects and has been seen to have a negative effect on a child's physical and emotional development, decreases academic performance and causes communication problems in work and family life. As a result, abuse of children is a widespread problem that negatively affects economic and social development and decreases the quality of life of all humanity (8).

The sexual abuse of children is one of the most difficult abuse types to diagnose and because of the difficulties in diagnosis, chronic cases are frequently seen. A child victim of sexual abuse may hide the abuse they have suffered for many years because

Table 4 . The time from the incident of abuse to presentation at the centre

\begin{tabular}{|l|l|l|}
\hline Time period & Number of children $(\mathbf{n})$ & Percentage $(\%)$ \\
\hline$>1$ week & 66 & 64.1 \\
\hline 1 day-1 week & 28 & 28.2 \\
\hline$<24$ hours & 8 & 7.8 \\
\hline
\end{tabular}

Table 5. The relationship between the child and the perpetrator

\begin{tabular}{|c|c|c|c|c|}
\hline & & & $\begin{array}{l}\text { Number of } \\
\text { children (n) }\end{array}$ & $\begin{array}{l}\text { Percentage } \\
(\%)\end{array}$ \\
\hline \multirow{10}{*}{$\begin{array}{l}\text { Known } \\
\text { to the } \\
\text { victim }\end{array}$} & \multirow{5}{*}{$\begin{array}{l}\text { Family } \\
\text { member }\end{array}$} & Cousin & 6 & 5.8 \\
\hline & & Father & 5 & 4.9 \\
\hline & & Maternal uncle & 2 & 1.9 \\
\hline & & $\begin{array}{l}\text { Uncle by } \\
\text { marriage }\end{array}$ & 6 & 5.8 \\
\hline & & Paternal uncle & 2 & 1.9 \\
\hline & \multirow{5}{*}{$\begin{array}{l}\text { Outside } \\
\text { the } \\
\text { family }\end{array}$} & Friend & 20 & 19.4 \\
\hline & & Boyfriend & 19 & 18.4 \\
\hline & & $\begin{array}{l}\text { Spouse from } \\
\text { a religious } \\
\text { marriage }\end{array}$ & 3 & 2.9 \\
\hline & & Teacher & 7 & 6.8 \\
\hline & & Other & 24 & 23.3 \\
\hline \multicolumn{3}{|c|}{ Stranger } & 9 & 8.7 \\
\hline
\end{tabular}


of fear, threats, the idea that they will not be believed or the belief that it is a shameful situation. Thus, there are victims who have been exposed to repeated abuse over many years. For the above-mentioned reasons, there is a need for increased societal awareness of child sexual abuse, which could be achieved by several professional organizations working together to focus on this subject.

With this knowledge and awareness, an evaluation was made in this study of 103 children presented at our centre, claiming to be a victim of abuse. The children comprised 86 (83.5\%) females and $17(16.5 \%)$ males that gave a male/female ratio of 0.19 . Many studies conducted on this subject have reported that girls are exposed to sexual abuse at higher rates than boys $(9,10)$. In a study conducted by Demirci et al. (11) the cases were $22.2 \%$ male and $77.8 \%$ female, Aydin et al. (12) the cases were $80 \%$ female and in another study conducted by Korkmaz et al. (13) $26 \%$ male and $74 \%$ female. Similarly, in a study of 158 cases by Kocak and Alparslan (14), the gender rates were $17.7 \%$ male and $82.3 \%$ female. The male and female rates of the current study were seen to be consistent with the literature.

When evaluating signs of sexual abuse, findings related to a decrease in academic success and interruptions in education are noticeable (15). In a study conducted by Koçak and Alparslan (14) it was reported that 31 cases left primary school without finishing their education and although five children finished primary school, they did not continue at high school. Dönmez et al. (16) reported that 11 children left primary school and 12 left high schools before finishing, while six children finished primary school but did not continue at high school $(14,16)$. In the current study, most cases were seen to be primary school students ( $n=32,31.1 \%)$, followed by high school students $(n=23$, $22.3 \%)$, and in two (1.9\%) cases, there was no information in the files about their education.

At the time of the forensic and medical evaluations, 76 (75.2\%) children were in formal education and 25 (24.8\%) discontinued formal education. In the evaluation of these results, just as sexual abuse could cause a cessation of education for the child victims, it should be kept in mind that remaining outside the education system could be a factor facilitating the exposure of these children to sexual abuse.

When the medical histories of the children were examined, 80 (77.7\%) children were observed to have no physical or mental disease. The most commonly seen condition was mental retardation in eight (7.8\%) cases. When mental retardation was evaluated as a risk factor for sexual abuse, this finding was consistent with the literature. In the light of this medical fact, all the professional groups involved in this subject should show greater care and attention to children with physical and mental disabilities. However, as this definition is not a medical definition, it includes many unexplained questions. Just as it is not known in which group a finger inserted into the mouth of a child for sexual purposes will be evaluated, the border of the internal and external opening in the genital region defines the anatomic localisation is clearly a matter for debate. Therefore, it is recommended that the classification of abuse is distanced from such a differentiation both legally and medically.

In the current study, it was seen that the victims aged $<10$ years and $>15$ years were statistically more often subjected to vaginal, anal and oral penetration, and those in the 10-14 years age group suffered abuse incidents such as indecent exposure, verbal sexual abuse, and touching (value: 16.845, $\mathrm{p}<0.001$ ). In children aged $<10$ years, a low level of sexual knowledge, physical incapacity and difficulties in asking for help could be a factor in both that they can be deceived or persuaded and in the progression to a more severe table of sexual abuse. In the group aged $>15$ years, in parallel with the features of adolescence, there is increased sexual interest and it has been thought that willingness towards the opposite sex and early marriages could progress to severe points in the dimension of abuse. Further, more extensive studies would be useful for the statistical validity of this relationship.

In the study conducted by Kocak and Alparslan (14) the most common type of abuse reported by the victims was vaginal penetration at 32\%, followed by sexual touching at $29.9 \%$ (14). Dönmez et al. (16) reported sexual contact in $89.8 \%$ of victims and penetration in $46 \%$ (16). In 51 cases evaluated by Shaw and Lewis because of sexual abuse, touching was reported in $70 \%$, genital rubbing in 45\%, vaginal penetration in 16\%, oral/genital contact in 38\%, anal rubbing in 23\%, anal penetration in $17 \%$ and penetration with an object in 12\% (17).

Similar rates are also seen in a study conducted with 1,002 cases in our country: "Vaginal, anal, and/or oral penetration were determined in $41.1 \%$ of the cases" (12).

In the current study, types of abuse were reported as touching of the child in 60 (58.3\%) cases, kissing in 16 (15.5\%) cases, indecent exposure in three (2.9\%) cases and verbal sexual abuse in $10(9.7 \%)$ cases, while in $32(31.1 \%)$ cases, vaginal penetration was recorded, in 21 (20.4\%) cases, anal penetration, and in six (5.8\%) cases, oral contact (mouth-penis). Although these findings are consistent with the literature, the high number of types of sexual abuse involving contact could be explained by them requiring less communication than types, such as verbal sexual abuse and indecent exposure.

When the examination was conducted of the time from the incident of abuse to examination at the centre, more than one week was seen to have passed in 66 (64.1\%) cases, between one and seven days in 28 (28.2\%) cases, and only eight (7.8\%) cases presented within 24 hours of the incident. In a study conducted by Yanal (18), only four cases were reported to have been taken for examination within 24 hours and Demirci et al. (11) stated that five of 275 cases presented in the first 24 hours $(11,18)$. 
In Yanal's study (18), in the anogenital examination, there was evidence of buggery in 62 (22.3\%) of 278 cases and no physical findings of buggery were determined in 216 (77.7\%) cases. In the genital examination, physical findings were determined in 60 (26.7\%) of 225 cases, and no physical findings were determined in 165 (73.3\%) cases (18). Demirci et al. (11) reported that in the hymen examination, an old tear was determined in 50 of 136 cases and a new tear in eight cases. In the anal examination, there were acute findings of buggery in seven of 115 cases and findings of chronic buggery in three (11). In a study by Korkmaz et al. (13) physical findings were determined in 56 of 258 cases (13).

In the current study, physical findings were regarding hymenal laceration in 20 (19.4\%) cases, of which 18 were old and two were new, extragenital ecchymosis was seen in six (5.8\%) cases, genital ecchymosis in two (1.9\%) cases, fissure in the anal region in two (1.9\%) cases, both of which were male, hymenal petechiae in two (1.9\%) cases and genital bleeding in two (1.9\%) cases.

To be able to obtain physical and biological evidence, it is very important that the children are examined as soon as possible after the incident of abuse before they have been to the toilet or had a bath. Both in the current study and previous reports in the literature, the low rates of physical findings determined could be explained by the delay in bringing the victim for examination.

In many cases of abuse, the degree of relationship of the victim to the perpetrator affects the type of abuse and the length of time that it is kept hidden. Incest cases are chronic at a higher rate than other cases, and when it has continued for many years for various reasons, it leaves more severe effects on the victim, which are difficult to repair.

Incest is defined as sexual activity between individuals closely related by blood, including relatives and family members with whom marriage is forbidden by law $(19,20)$. Another definition is the type of abuse perpetrated on a child by a blood relative or an individual responsible for their care (21). In addition, abuse enacted by a stepmother, father or any relative with authority over the child or any other person living in the same house should be evaluated as incest (21).

When the relationship between the child and the alleged perpetrator of the abuse was examined, it was seen that the perpetrator was known to the child in some way in 94 (91.3\%) cases and was a stranger in only nine (8.7\%) cases. In a study conducted by Nickel et al. (22) it was reported that the perpetrator was known to the victim in $50.3 \%$ of cases (22). Csorba et al. (23) stated that the perpetrator was a relative or an individual previously known to the child in $66 \%$ of cases and a stranger in 34\%. Kocak and Alparslan (14) reported that the perpetrator was known to the child in $77.2 \%$ of the cases $(14,23)$.
In the current study, the perpetrator of the abuse was a family member in 21 (20.4\%) cases, the boyfriend of the child in $19(18.4 \%)$ cases and the husband from a religious marriage ceremony in three (2.9\%) cases. Of the cases of abuse within the family, the abuser was a cousin in six cases, an uncle by marriage in six cases, and the father in five cases. In a study conducted by Yılmaz and Eryılmaz (19) the perpetrator of abuse was reported to be the father in seven cases, the step-father in five cases, an uncle by marriage in eight cases and a cousin in seven cases (19). A study conducted by Yildirim et al. (24) showed the most common form of incest to be father-daughter at a rate of $34.9 \%$ (24). The findings of the current study were consistent with the literature.

Sexual abuse is the most difficult type of abuse to diagnose and combat. Moreover, sexual abuse leads to the deepest wounds in society. Therefore, the fight against sexual abuse can only be won not just by those involved but through an approach to this subject with sensitivity and common values of all society. Regular community education programs to raise awareness and consciousness of this subject may reduce the rates of abuse. In collaboration with this work, the rehabilitation processes of the child victims of abuse can be accelerated.

Another point that is just as difficult to deal with as the effects of the trauma suffered by the child victims of sexual abuse is the legal process. When the judicial process starts with the repeated taking of statements and repeated examinations, rather than being spared the effects of the trauma, traumatization is deepened. In Turkey, the most effective way of protecting the victims is the Child Protection and Advocacy Centers, which are increasing in number and range of services provided. These centers gather the experts from all sides of this subject under one roof so that the necessary procedures can be performed correctly and at one time by specialists in the case of the child. Then, rapid and effective decisions can be taken, and thus they should become institutions that are not only diagnostic, but that can also provide treatment and rehabilitation services. The numbers of these centers should be increased with the provision of the necessary facilities to be able to work actively. As can be seen in this study, there are still high numbers of marriages at a young age in Turkey and this is a cultural wound that has a negative effect on the physical and mental development of children. The way to combat early marriage should be to provide effective methods of education for children and adolescents on both the realities of age and sexual subjects. Sexual health and sexual development lessons included in the education system would be effective for children and adolescents.

At the same time, it seems that a high proportion of child victims of abuse drop out of education or have never started school. This is a situation that should be eradicated with speed and sensitivity. In addition to supportive programs in schools 
for children who are still integrated into the education system, ways should be found to include children who remain outside the system.

\section{CONCLUSION}

In conclusion, the fight against child abuse is not one that can be won by a cross-section of society. Collective awareness and public spirit are required, and it must not be forgotten that every effort made to protect our children in this struggle is belief, trust and hope for the future.

\section{ETHICS}

Ethics Committee Approval: This study was reviewed and approved by Karadeniz Technical University Faculty of Medicine Research and Ethics (18/07/2016-24237859-434) Committee.

Peer-review: Internally peer-reviewed.

\section{Authorship Contributions}

Surgical and Medical Practices: G.S.K., H.I.A., M.A., Concept: G.S.K., E.Ö., I.B., M.I., Design: G.S.K., E.Ö., I.B., M.I.., Data Collection or Processing: G.S.K., E.Ö., I.B., H.I.A., M.A., Analysis or Interpretation: G.S.K., E.Ö., I.B., H.I.A., M.I., Literature Search: G.S.K., E.Ö., İ.B., H.I.A., M.A., Writing: G.S.K., H.I.A.

Conflict of Interest: No conflict of interest was declared by the authors.

Financial Disclosure: The authors declared that this study received no financial support.

\section{REFERENCES}

1. Prior V, Glaser D, Lynch MA. Responding to child sexual abuse: the criminal justice system. Child Abuse Rev. 1997;6:128-140.

2. Pressel DM. Evaluation of physical abuse in children. Am Fam Physician 2000;61:3057-3064.

3. Kara Y, Özgün-Koca SA. Buluş yoluyla öğrenme ve anlamlı öğrenme yaklaşımlarının matematik derslerinde uygulanması:" Iki terimin toplamının karesi" konusu üzerine iki ders planı. Elementary Education Online. 2004 Mar 1;3(1).

4. American Academy of Pediatrics Committee on Child Abuse and Neglect: Guidelines for the evaluation of sexual abuse of children. Pediatrics. 1991;87(2):254-260.

5. Taner Y, Gökler B. Çocuk istismar ve ihmali: Psikiyatrik yönleri. Hacettepe Tıp Derg. 2004;35:82-86.

6. Keskinkılıç H. Erciyes Üniversitesi Hastanelerine Başvuran Çocuk Cinsel İstismarı Olgularının Değerlendirmesi. [Tıpta uzmanlık Tezi], 2014, Kayseri
7. Trabzon Barosu Çocuk Hakları Komisyonu Çocuk İzlem Merkezleri Türkiye Raporu Nisan. Erișim Adresi: http://web.e-baro.web.tr/uploads/61/2015/ cim\%20tr.pdf

8. WHO. Dünya Sağıı Örgütü. 2014. Available from: http://www.who.int/ violence_injury_prevention/iolence/

9. Magalhães T, Carneiro de Sousa MJ, Gomes da Silva A, Pinto da Costa D, Grams AC, Ribeiro C, et al. Child sexual abuse: a preliminary study. J Clin Forensic Med. 1998;5(4):176-182.

10. Finkelhor D. The international epidemiology of child sexual abuse. Child Abuse Negl. 1994;18(5):409-417.

11. Demirci Ș, Doğan KH, Erkol Z, Deniz İ. Evaluation of child case examined for sexual abuse in Konya. Türkiye Klinikleri J Foren Med. 2008;5:43-49.

12. Aydin B, Akbas S, Turla A, Dundar C, Yuce M, Karabekiroglu K. Child sexual abuse in Turkey: an analysis of 1002 cases. J Forensic Sci. 2015 Jan;60(1):615. doi: 10.1111/1556-4029.12566. Epub 2014 Jul 25. PMID: 25066376.

13. Korkmaz M, Uysal C, Sivri S, Bozkurt I, Bulut K, Şimșek Ș, Haspolat K, ve ark Cinsel Saldırı Sonrası Adli Tıp Bölümüne Bșvuran Olguların Beden ve Ruh Sağlıklarının Değerlendirilmesi. Dicle Tıp Derg. 2014;41(4):656-661.

14. Koçak U, Alparslan AH. Cinsel istismara uğrayan çocuk ve ergenlerin sosyodemografik özellikleri ve ruhsal değerlendirilmesi. Adli Tıp Bülteni. 2015;20(1):27-33.

15. Polat O, Tüm boyutlarıyla çocuk istismarı. Ankara: Seçkin Yayınları; 2007:93.

16. Dönmez YE, Soylu N, Özcan Ö, Yüksel T, Çalışkan Demir A, et al. Cinsel istismar mağduru çocuk ve ergen olgularımızın sosyodemografik ve klinik özellikleri, J Turgut Özal Med Cent. 2014;21(1):44-48.

17. Shaw JA, Lewis JE. Child on child sexual abuse: psychological perspectives Child Abuse Negl. 2000;24(12):1591-1600.

18. Yanal S. Çocuklara yönelik cinsel istismar olgularının değerlendirilmesi ve uygulamada yașanan sorunlar [tez] Kocaeli Üniversitesi Tıp Fakültesi, 2013.

19. Yılmaz R, Eryılmaz A. Bülent Ecevit Üniversitesi Hastanesinde değerlendirilen ensest olgularının sosyodemografik özellikleri. Adli Tıp Bülteni. 2016;21(3):167-171.

20. Kellogg $N$. The evaluation of sexual abuse in children. Pediatrics. 2005;116(2):506-512.

21. Balcı Y. Herkes İçin Adli Tıp. 1. baskı. Eskișehir: Eskișehir Osmangazi Üniversitesi Basımevi; 2008: 237.

22. Nickel MK, Tritt K, Mitterlehner FO, Leiberich P, Nickel C, Lahmann C, et al. Sexual abuse in childhood and youth as psychopathologically relevant life occurrence: cross-sectional survey. Croat Med J. 2004;45(4):483-489.

23. Csorba R, Aranyosi J, Borsos A, Balla L, Major T, Póka R. Characteristics of female child sexual abuse in Hungary between 1986 and 2001: a longitudinal, prospective study. Eur J Obstet Gynecol Reprod Biol. 2005;120(2):217-221.

24. Yildirim A, Ozer E, Bozkurt H, Ozsoy S, Enginyurt O, Evcuman D, et al. Evaluation of social and demographic characteristics of incest cases in a university hospital in Turkey. Med Sci Monit. 2014;20:693-697. 